\title{
On the ability of $\mathrm{CuA} \beta_{1-\mathrm{x}}$ peptides to form ternary complexes: Neurotransmitter glutamate is a competitor while not a ternary partner
}

\author{
Tomasz Frączyk ${ }^{\text {, }}$, Izabela A. Zawisza ${ }^{\text {a }}$, Wojciech Goch ${ }^{\text {a }}$, Ewelina Stefaniak ${ }^{\text {a }}$, Simon C. Drew ${ }^{\text {b }}$, Wojciech Bal ${ }^{\text {a,* }}$ \\ a Institute of Biochemistry and Biophysics, Polish Academy of Sciences, Pawińskiego 5a, 02-106 Warsaw, Poland \\ ${ }^{\mathrm{b}}$ Florey Department of Neuroscience and Mental Health, The University of Melbourne, Victoria, 3010, Australia
}

\section{A R T I C L E I N F O}

\section{Article history:}

Received 12 October 2015

Received in revised form 23 February 2016

Accepted 28 February 2016

Available online $\mathrm{xxxx}$

\section{Keywords:}

$\mathrm{Cu}(\mathrm{II})-\mathrm{A} \beta$ complexes

glutamic acid

ternary complexes

\begin{abstract}
A B S T R A C T
In the light of conflicting reports on the ability of copper(II) complexes of amyloid beta (A $\beta$ ) peptides to form ternary complexes with small molecules co-present in the biological milieu, we performed a study of coordination equilibria in the system containing $\mathrm{Cu}(\mathrm{II})$ ions, the $A \beta_{1-16}$ peptide, glutamic acid and 4-(2-hydroxyethyl)-1piperazineethanesulfonic acid (2-[4-(2-hydroxyethyl)piperazin-1-yl]ethanesulfonic acid, HEPES) buffer. Using potentiometry, isothermal titration calorimetry (ITC), UV-visible spectroscopy and EPR, we concluded that glutamic acid was not able to form such a ternary complex, but can efficiently compete for the $\mathrm{Cu}$ (II) ion with the $A \beta$ peptide at Glu concentrations relevant for the synaptic cleft. We also found that the literature constants for $\mathrm{Cu}$ (II) complexes with Glu were overestimated, but this effect was partially compensated by the formation of a ternary $\mathrm{Cu}(\mathrm{Glu})(\mathrm{HEPES})$ complex. Our results indicate that small molecules co-present with $\mathrm{Cu}$ (II) ions and $A \beta$ peptides in the synaptic cleft are not very likely to enhance $\mathrm{Cu}(\mathrm{II}) / \mathrm{A} \beta$ interactions, but instead should be considered as a $\mathrm{Cu}$ (II) buffering system that may help prevent these interactions and participate in $\mathrm{Cu}$ (II) clearance from the synaptic cleft.
\end{abstract}

(c) 2016 Elsevier Inc. All rights reserved.

\section{Introduction}

The $\mathrm{Cu}(\mathrm{II})$ interactions with $A \beta$ peptides, predominantly $A \beta_{1-42}$ and $A \beta_{1-40}$, have been implicated in the etiology of Alzheimer's Disease (AD) [1-4]. Major lines of evidence described in the literature include association of $\mathrm{Cu}(\mathrm{II})$ ions with amyloid plaques composed of $A \beta$ peptides isolated from post-mortem $A D$ brains, enhancement of $A \beta$ aggregation by $\mathrm{Cu}(\mathrm{II})$ ions, and support of $\mathrm{Cu}(\mathrm{II}) / \mathrm{Cu}(\mathrm{I})$ redox cycling by the $A \beta$ peptides, yielding deleterious reactive oxygen species. Monomeric $A \beta$ peptides bind one $\mathrm{Cu}(\mathrm{II})$ ion with a conditional stability constant at pH $7.4\left({ }^{C} K_{7.4}\right)$ of $10^{10} \mathrm{M}^{-1}$, and another at least 100 times weaker $[5,6]$. These relatively low stability constants, determined for both the short model peptide $A \beta_{1-16}$, as well as the physiologically relevant $A \beta_{1-40}$ species, may be considered to weaken the proposal associating the $A \beta$ neurotoxicity with $\mathrm{Cu}(\mathrm{II})$ binding, because of the presence of stronger $\mathrm{Cu}$ (II) ligands in the brain. Human serum albumin (HSA), which binds one $\mathrm{Cu}(\mathrm{II})$ ion with ${ }^{\mathrm{C}} K_{7.4}$ of $10^{12} \mathrm{M}^{-1}$ [7], is abundant in the cerebrospinal fluid at a micromolar level [8]. Thus, a higher

Abbreviations: $A \beta$, amyloid beta peptides; $A \beta_{1-16}$, DAEFRHDSGYEVHHQK-amide; $A D$, Alzheimer's Disease; B, fully deprotonated HEPES buffer molecule; ${ }^{C} K_{7.4}$, conditional affinity constant at $\mathrm{pH}$ 7.4; HEPES, 4-(2-hydroxyethyl)-1-piperazineethanesulfonic acid or 2[4-(2-hydroxyethyl)piperazin-1-yl]ethanesulfonic acid; ITC, Isothermal Titration Calorimetry; L, fully deprotonated glutamic acid molecule; PBT2, 5,7-dichloro-2[(dimethylamino)methyl]quinolin-8-ol.

* Corresponding author.

E-mail address: wbal@ibb.waw.pl (W. Bal). conditional stability constant for $\mathrm{Cu}(\mathrm{II})$ binding, compared with $\mathrm{A} \beta_{1-\mathrm{x}}$ peptides, co-localization with these peptides, and a high abundance of HSA suggest that this protein could effectively compete for $\mathrm{Cu}(\mathrm{II})$ with $A \beta_{1-x}$ peptides. Indeed, this protein was shown to withdraw $\mathrm{Cu}$ (II) from $A \beta_{1-x}$ peptides directly and quickly, and was suggested by several research groups, including us, to be a "brain guardian" preventing $A \beta-$ associated copper toxicity [9-12]. Recently, we combined our experimental results with previous analytical reports to show that another $A \beta$ species, namely $A \beta_{4-x}(x=16$ is the model peptide, $x=42$ is a dominant brain species) binds one $\mathrm{Cu}$ (II) ion with ${ }^{C} K_{7.4}$ of $3.4 \times 10^{13} \mathrm{M}^{-1}$, and withdraws $\mathrm{Cu}(\mathrm{II})$ from the $\mathrm{A} \beta_{1-\mathrm{x}}$ species quantitatively within the time required for sample mixing [13]. Taking into account numerous reports that $A \beta_{4-x}$ species are at least as abundant as the $A \beta_{1-x}$ species in both healthy and AD brains [14-17], and that the main $\mathrm{Cu}$ (II) complex of the $A \beta_{4-x}$ peptide is redox inactive, one can wonder whether the $\mathrm{Cu}(\mathrm{II})$-mediated $\mathrm{A} \beta$ toxicity may ever occur in vivo.

One way of resolving this dilemma is by considering that the aggregated $A \beta_{1-x}$ peptides could bind $\mathrm{Cu}(\mathrm{II})$ more strongly than the monomeric peptide. This idea was tested experimentally by two research groups, but conflicting results were obtained (i.e. no enhancement $v s$. a significant and progressive enhancement) $[18,19]$. However, the highest enhancement of binding reported [19] still would not overcome the affinity characteristic of the $A \beta_{4-x}$ peptides [13].

The formation of ternary complexes could be another way of enhancing $\mathrm{Cu}(\mathrm{II})$ binding to $A \beta_{1-\mathrm{x}}$ peptides. The susceptibility of model 
peptide $A \beta_{1-16}$ to formation of ternary complexes with small molecules and common buffers was postulated in our early paper [20]. Further research did not yield evidence for such abilities of HEPES buffer, but a recent report indicated the formation of a ternary Tris complex (although the reaction was studied only at $\mathrm{pH} 4$.0) [21]. In our recent paper we demonstrated that $A \beta_{1-16}$ was able to form a ternary $\mathrm{Cu}(\mathrm{II})$ complex with 2[(dimethylamino)methyl]-8-hydroxyquinoline, an analog of the experimental drug PBT2 (5,7-dichloro-2-[(dimethylamino)methyl]quinolin-8ol) which was designed to compete $\mathrm{Cu}$ (II) from the $\mathrm{A} \beta$ complex [22]. Consideration of the most sui candidates for a ternary ligand in vivo led us to propose glutamic acid (Glu), since AD pathology initially affects glutamatergic synapses and the concentrations of Glu in these synapses during neurotransmission may exceed $1 \mathrm{mM}$ [23]. We therefore sought to identify ternary complexes in the $\mathrm{Cu}(\mathrm{II}) / \mathrm{A} \beta_{1-16} / \mathrm{Glu}$ system.

\section{Experimental}

\subsection{Potentiometry}

Potentiometric titrations of the $\mathrm{Cu}$ (II)/Glu and $\mathrm{Cu}$ (II)/Glu/HEPES systems were performed on a Titrando 907 automatic titrator (Metrohm), using a combined glass- $\mathrm{Ag} / \mathrm{AgCl}$ electrode (InLab®Micro, Mettler Toledo, Switzerland), which was calibrated daily by nitric acid titrations [24]. 0.1 M NaOH (carbon dioxide free) was used as titrant. Sample volumes of $1.0-1.5 \mathrm{~mL}$ were used. For the binary $\mathrm{Cu}(\mathrm{II}) / \mathrm{Glu}$ system the samples contained $0.5-1.0 \mathrm{mM}$ Glu free acid, dissolved in $4 \mathrm{mM} \mathrm{HNO}_{3} / 96 \mathrm{mM} \mathrm{KNO}_{3}$. The $\mathrm{Cu}(\mathrm{II})$ complex formation was studied for $1: 2,1: 2.5$, and $1: 3$ metal-to-ligand stoichiometries, using $\mathrm{Cu}(\mathrm{II})$ added as $\mathrm{Cu}\left(\mathrm{NO}_{3}\right)_{2}$. For the ternary system, the following sets of millimolar $\mathrm{Cu}(\mathrm{II}) / \mathrm{Glu} / \mathrm{HEPES}$ concentrations were used: 1/2/2, 1/1/4 and $0.5 / 1 / 4$. All experiments were performed under argon at $25{ }^{\circ} \mathrm{C}$, in the $\mathrm{pH}$ range 2.3 to 12.2 . The collected data were analyzed using the SUPERQUAD and HYPERQUAD programs [25,26]. Three to five titrations were included simultaneously into calculations, separately for Glu and HEPES protonation, binary $\mathrm{Cu}$ (II) complexes and the ternary system.

\subsection{UV-visible (UV-vis) spectroscopy}

UV-vis spectroscopy was used to characterize the formation of $\mathrm{Cu}(\mathrm{II})$ complexes with Glu, HEPES, and $\mathrm{A} \beta_{1-16}$ (synthesized according to the Fmoc strategy and purified in our laboratory as described [13]). The UV-vis spectra were recorded at $25^{\circ} \mathrm{C}$ on a LAMBDA $950 \mathrm{UV} / \mathrm{vis} /$ NIR spectrophotometer (PerkinElmer), over the spectral range of 250$850 \mathrm{~nm}$. The optical path for all experiments was $1 \mathrm{~cm}$. The concentration of $A \beta_{1-16}$ was determined using an extinction coefficient of $1400 \mathrm{M}^{-1} \mathrm{~cm}^{-1}$ at $275 \mathrm{~nm} \mathrm{[13].}$

In acid/base titrations of $\mathrm{Cu}(\mathrm{II}) / \mathrm{Glu}$ and $\mathrm{Cu}(\mathrm{II}) / \mathrm{Glu} / \mathrm{HEPES}$ systems, $0.5 \mathrm{mM} \mathrm{Cu}(\mathrm{II}), 0.45: 1 \mathrm{Cu}(\mathrm{II})$-to-Glu molar ratio, and 0.45:1:1 Cu(II)to-Glu-to-HEPES molar ratio were used. The samples were titrated with $\mathrm{NaOH}$ by careful manual additions of very small amounts of the concentrated base solution, in the $\mathrm{pH}$ range of 2.9-11.0.

In separate experiments $\mathrm{Cu}(\mathrm{II}) / \mathrm{A} \beta_{1-16}$ (0.9:1 ratio) or $\mathrm{Cu}(\mathrm{II}) / \mathrm{Glu}$ (0.9:1 ratio) in $50 \mathrm{mM}$ HEPES ( $\mathrm{pH} 7.4$ ) was titrated with $40 \mathrm{mM}$ Glu in the same buffer, to the final excess of Glu over $\mathrm{Cu}$ (II) of 77 for each sample. The initial concentrations of $\mathrm{Cu}$ (II) were equal to $0.5 \mathrm{mM}$.

\subsection{Isothermal titration calorimetry (ITC)}

Calorimetric titrations were carried out on the Nano ITC Standard Volume calorimeter (TA Instruments). The sample cell $(950 \mu \mathrm{L})$ was filled with a $\mathrm{Cu}(\mathrm{II})$ and $A \beta_{1-16}$ solution (with metal to peptide ratio of 0.9:1) in $50 \mathrm{mM}$ HEPES buffer at pH 7.4. Concentrations of the resulting $\mathrm{Cu}(\mathrm{II}) / \mathrm{A} \beta_{1-16}$ complex were within the range of $48-600 \mu \mathrm{M}$. The syringe $(250 \mu \mathrm{L})$ was loaded with $10 \mathrm{mM}$ Glu in $50 \mathrm{mM}$ HEPES at pH 7.4.
Typically, $8 \mu \mathrm{L}$ of the Glu solution was added to the $\mathrm{Cu}(\mathrm{II}) / \mathrm{A} \beta_{1-16} \mathrm{com}-$ plex solution at $1000 \mathrm{~s}$ intervals using a stirring speed of $200 \mathrm{rpm}$. The measurements were performed at $25^{\circ} \mathrm{C}$.

\subsection{EPR spectroscopy}

Samples containing $\mathrm{Cu}(\mathrm{II}) / \mathrm{A} \beta_{1-16} / \mathrm{Glu}$ in the ratio $1: 1: n(n=0-100)$ were prepared in $20 \mathrm{mM}$ HEPES $\mathrm{pH}$ 6.9. Copper was added from a $10 \mathrm{mM}^{65} \mathrm{CuCl}_{2}$ stock to a final concentration of $200 \mu \mathrm{M}$, with $10 \% v / \mathrm{v}$ glycerol was included as a cryoprotectant as described previously [22, 27]. Reference spectra corresponding to $\mathrm{CuA} \beta_{1-16}$ and $\mathrm{CuGlu}_{2}$ were obtained using $\mathrm{Cu}(\mathrm{II}) / \mathrm{A} \beta_{1-16} \quad 0.9: 1$ and $\mathrm{Cu}(\mathrm{II}) / \mathrm{Glu}$ 1:50 mixtures, respectively.

X-band $(9.45 \mathrm{GHz})$ continuous-wave EPR spectra were obtained at $77 \mathrm{~K}$ using a Bruker Elexsys E500 spectrometer fitted with a Bruker super-high-Q probehead (ER 4122SHQE) and a quartz cold finger insert (Wilmad, WG-816-B-Q). The following experimental settings were used: microwave frequency, $9.45 \mathrm{GHz}$; microwave power, $10 \mathrm{~mW}$; magnetic field modulation amplitude, $5 \mathrm{G}$; field modulation frequency, $100 \mathrm{kHz}$; receiver time constant, $164 \mathrm{~ms}$; receiver gain, $56 \mathrm{~dB}$; sweep rate, 6.67 gauss $\mathrm{s}^{-1}$. Baseline correction was performed by subtraction of a spectrum of buffer only.

To deconvolute the $\mathrm{Cu}(\mathrm{II}) / \mathrm{A} \beta_{1-16} / \mathrm{Glu} 1: 1: n$ spectra, all of the experimental first-harmonic spectra were first normalized by doubleintegration. A reconstruction of the $\mathrm{Cu}(\mathrm{II}) / \mathrm{A} \beta_{1-16} / \mathrm{Glu} 1: 1: n$ spectra was then made by weighted addition of normalized $\mathrm{CuA} \beta_{1-16}$ and $\mathrm{Cu}(\mathrm{Glu})_{2}$ spectra, with the weightings adjusted in order to minimize the mean-squared deviation between the reconstruction and the $\mathrm{Cu}$ / $A \beta_{1-16} /$ Glu 1:1: $n$ spectrum. The speciation of the CuGlu spectral component was at most only a few percent for all conditions and was therefore not explicitly included in the fits.

\subsection{Computational methods}

Calculations were performed with the use of a custom-made software implemented in the Wolfram Mathematica 9 environment, which serves the purpose of determination of binding constants in an investigated system, along with the deconvolution of spectroscopic data in the course of the fitting procedure.

The binding constants for $\mathrm{Cu}(\mathrm{II}) / \mathrm{Glu}$ and $\mathrm{Cu}(\mathrm{II}) / \mathrm{Glu} / \mathrm{HEPES}$ systems were obtained from potentiometric experiments. The species concentration curves were calculated from these binding constants and deconvolution of the spectra was performed by the linear least square fitting to the aforementioned curves. The UV-vis spectra of $\mathrm{CuHL}^{+}$, $\mathrm{CuL}$ and $\mathrm{CuL}_{2}^{2-}$ complex species (L denotes fully deprotonated glutamic acid molecule) were obtained by global deconvolution of acid/base titrations and Glu titrations of the $\mathrm{Cu}(\mathrm{II}) / \mathrm{HEPES}$ samples. The spectrum of the CuLB ${ }^{-}$complex (B denotes fully deprotonated HEPES buffer molecule) was obtained from the deconvolution of $\mathrm{pH}$ titration spectra in the presence of HEPES, with all other spectra fixed. Subsequently, the results of the deconvolution were applied to the experiment in which the $\mathrm{Cu}(\mathrm{II}) / \mathrm{A} \beta_{1-16}$ samples were titrated with Glu. The full set of UV-vis spectra was fully explained by the competition model where the $\mathrm{Cu}$ (II) ion was largely transferred from the CuA $\beta_{1-16}$ complex to the $\mathrm{CuL}_{2}^{2-}$ complexes. To account for the dilution of sample constituents, actual total concentrations of $\mathrm{Cu}(\mathrm{II})$, $A \beta_{1-16}$, Glu, and HEPES were considered in calculations for every corresponding raw spectrum.

In the calorimetric experiments satisfactory fits were obtained for the competition reaction model where $\mathrm{Cu}(\mathrm{II})$ ions were extracted from the $\mathrm{CuA} \beta_{1-16}$ complex to CuL and subsequently $\mathrm{CuL}_{2}^{2-}$ complexes, with traces of the $\mathrm{CuLB}^{-}$complex. The assumption of a model including the formation of a ternary $\mathrm{CuA} \beta_{1-16} \mathrm{~L}$ complex had no significant impact on the quality of the fits. 


\section{Results}

\subsection{Preliminary studies}

Our initial strategy of determination of coordination equilibria in the $\mathrm{Cu}(\mathrm{II}) / \mathrm{A} \beta_{1-16} / \mathrm{Glu}$ system was based on three independent experimental methods. ITC titrations of equimolar $\mathrm{Cu}$ (II)/A $\beta_{1-16}$ samples with a glutamic acid solution were followed by deconvolution of titration curves with the affinity constants of both component binary systems $\left(\mathrm{Cu}\right.$ (II)/A $\beta_{1-16}$ and $\left.\mathrm{Cu}(\mathrm{II}) / \mathrm{Glu}\right)$ taken from previous studies. UV-vis studies were aimed at providing independent support for these deconvolutions, and EPR experiments were anticipated to provide us with parameters of the ternary complex(es) that would help us in deciphering its(their) structure.

The ITC experiments were performed in a $50 \mathrm{mM}$ HEPES buffer at $\mathrm{pH}$ 7.4. We used the ${ }^{\mathrm{C}} K_{7.4}$ value for the $\mathrm{CuA} \beta_{1-16}$ complex, established by spectroscopic titrations and the full set of logarithmic values of cumulative stability constants $(\log \beta)$ for the $\mathrm{Cu}(\mathrm{II}) / \mathrm{Glu}$ system presented in the literature [5]. The calculations performed using only the binary systems indicated a need to include additional species, which we initially interpreted as evidence for a ternary complex. The fits were, however, unsatisfactory (Fig. S1). We did not include HEPES in our initial considerations, because it would not interact with the $\mathrm{Cu}(\mathrm{II}) / \mathrm{A} \beta_{1-16}$ system under these experimental conditions [5,28], but then we realized that HEPES, present at a high molar excess over $\mathrm{Cu}(\mathrm{II})$ and Glu might interfere with the $\mathrm{Cu}(\mathrm{II}) / \mathrm{Glu}$ system, by forming a ternary complex [29]. Therefore we decided to re-evaluate the $\mathrm{Cu}(\mathrm{II}) / \mathrm{Glu} / \mathrm{HEPES}$ system by potentiometry and UV-vis spectroscopy and reanalyze the ITC results using the newly established stability constants.

\subsection{Potentiometric and UV-vis studies of the $\mathrm{Cu}(\mathrm{II}) / \mathrm{Glu} / \mathrm{HEPES}$ system}

These experiments started with the potentiometric and UV-vis studies of the $\mathrm{Cu}(\mathrm{II}) / \mathrm{Glu}$ system. The stability constants obtained by potentiometry are presented in Table 1 . The potentiometric results were validated by spectrophotometric $\mathrm{pH}$ titrations.

Examples of UV-vis acid/base titrations are shown in Fig. 1. In addition, we performed spectrophotometric titrations of $\mathrm{Cu}(\mathrm{II}) / \mathrm{Glu}$ (0.9:1) with Glu in $50 \mathrm{mM}$ HEPES at pH 7.4. The spectra from all titrations were pooled together in calculations, and deconvoluted according to the coordination model using the stability constants presented in Table 1 . The spectral parameters obtained are presented in Table 2.

Table 1

Protonation constants and stability constants of $\mathrm{Cu}(\mathrm{II})$ complexes ( $\log \beta$ values) of glutamic acid (L) and HEPES (B) at I $=0.1 \mathrm{M}\left(\mathrm{KNO}_{3}\right)$ and $25^{\circ} \mathrm{C}$.

\begin{tabular}{lll}
\hline Species & $\log \beta$ (this work) $^{\mathrm{a}}$ & $\log \beta$ (reference study) $^{\mathrm{b}}$ \\
\hline Glutamic acid & & \\
$\mathrm{H}_{3} \mathrm{~L}^{+}$ & $15.92(2)$ & 16.27 \\
$\mathrm{H}_{2} \mathrm{~L}$ & $13.811(9)$ & 13.99 \\
$\mathrm{HL}^{-}$ & $9.603(6)$ & 9.746 \\
$\mathrm{CuHL}^{+}$ & $12.82(2)$ & 12.73 \\
$\mathrm{CuL}$ & $8.24(1)$ & 8.545 \\
$\mathrm{CuH}_{2} \mathrm{~L}_{2}$ & n.d. & 25.18 \\
$\mathrm{CuHL}_{2}^{-}$ & n.d. & 20.57 \\
$\mathrm{CuL}_{2}^{2-}$ & $14.32(2)$ & 15.22 \\
$\mathrm{HEPES}^{\mathrm{c}}$ & & \\
$\mathrm{H}_{2} \mathrm{~B}^{+}$ & $10.53(1)$ & 10.397 \\
$\mathrm{HB}^{+}$ & $7.377(4)$ & 7.409 \\
$\mathrm{CuB}^{+}$ & $3.22^{\mathrm{d}}$ & 3.22 \\
$\mathrm{Ternary}$ & & \\
$\mathrm{CuLB}^{-}$ & $10.71(7)$ & n.d.
\end{tabular}

a Standard deviations on the least significant digits, provided by HYPERQUAD [24], are given in parentheses.

b Ref. [30] for Glu, ref. [28] for HEPES.

c n.d.; not detected.

d value not fitted, but found to be correct in the course of potentiometric calculations.

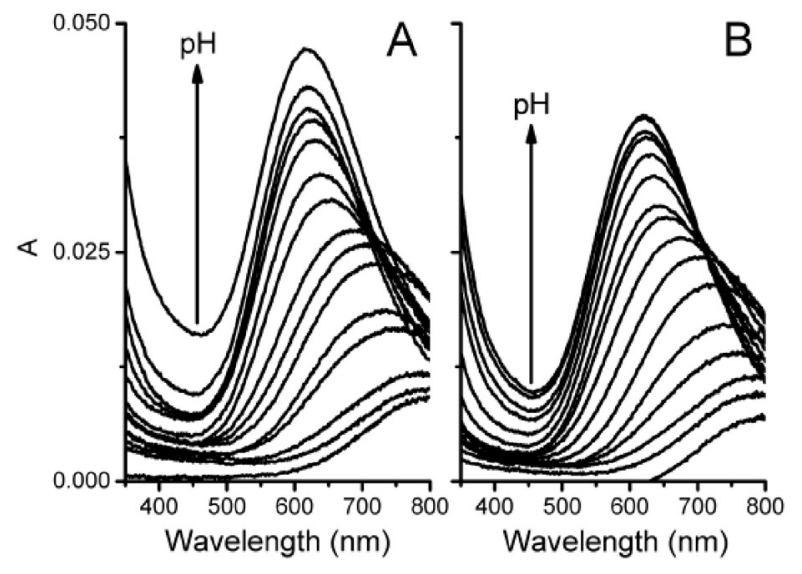

Fig. 1. UV-vis spectra of $\mathrm{Cu}$ (II) complexes with $\mathrm{Glu}(\mathrm{A})$ and with Glu/HEPES (B) at different $\mathrm{pH}$ values. The spectra were recorded at $25^{\circ} \mathrm{C}$ for samples containing $0.5 \mathrm{mM}$ $\mathrm{Cu}\left(\mathrm{NO}_{3}\right)_{2}$ and $1.2 \mathrm{mM}$ Glu or/and $1.2 \mathrm{mM}$ HEPES.

The deconvolution confirmed the presence of the ternary complex formed by $\mathrm{Cu}(\mathrm{II})$ with $\mathrm{Glu}$ and HEPES, with a $\mathrm{CuLB}^{-}$stoichiometry (Figs. 2, S2-S4).

\subsection{UV-vis and EPR studies of the $\mathrm{Cu}(\mathrm{II}) / \mathrm{A} \beta_{1-16} / \mathrm{Glu} / \mathrm{HEPES}$ system}

The next step was to perform UV-vis monitored titrations of the $\mathrm{Cu}(\mathrm{II}) / \mathrm{A} \beta_{1-16}$ system in HEPES at $\mathrm{pH} 7.4$ with a concentrated $(40 \mathrm{mM})$ Glu solution. These experiments allowed us to test the working hypothesis assuming the presence of ternary $\mathrm{Cu}(\mathrm{II}) / \mathrm{A} \beta_{1-16} / \mathrm{Glu}$ complexes. The model without a ternary complex fully explained changes of absorbance during titrations. The values of absorbance for selected wavelengths along with the best fit to the final coordination model are presented in Fig. 3. In line with the UV-vis observations, changes in the EPR spectra during titration of Glu into 1:1 $\mathrm{Cu}(\mathrm{II}) / \mathrm{A} \beta_{1-16}$ could be accounted for by the presence of only binary $C u A \beta_{1-16}$ and $\mathrm{CuGlu}_{2}$ complexes (Fig. 4).

\subsection{ITC studies of the $\mathrm{Cu}(\mathrm{II}) / \mathrm{A} \beta_{1-16} / \mathrm{Glu} / \mathrm{HEPES}$ system}

We also performed ITC experiments analogous to UV-vis titrations. First, from a titration of $A \beta_{1-16}$ in HEPES at $\mathrm{pH} 7.4$ with an aqueous $\mathrm{Cu}(\mathrm{II})$ solution we determined the $\Delta \mathrm{H}$ value for $A \beta_{1-16}(-34.7 \pm$ $1.6 \mathrm{~kJ} / \mathrm{mol}$ ), which we applied in the calculations of parameters of the four-component system where the Glu solution in HEPES was titrated to $\mathrm{Cu}(\mathrm{II}) / \mathrm{A} \beta_{1-16}$ samples in HEPES. Control experiments showed that Glu did not interact with HEPES and $A \beta_{1-16}$ in the absence of $\mathrm{Cu}$ (II) ions (Fig. S6 in the Supplementary Information file). For the $\mathrm{Cu}(\mathrm{II}) /$ $\mathrm{A} \beta_{1-16} / \mathrm{Glu} / \mathrm{HEPES}$ system we used a range of concentrations of $\mathrm{Cu}(\mathrm{II}) /$ $\mathrm{A} \beta_{1-16}$ samples from 0.048 to $0.600 \mathrm{mM}$, but maintained the concentrations of HEPES and added (syringe) Glu constant at 50 and $10 \mathrm{mM}$, respectively. Thus, the results were obtained for a range of ratios of HEPES and Glu to other reagents. This allowed us to test the existence of all potential ternary complexes. The global fit of the model assuming the following complexes: $\mathrm{CuA}_{1-16}, \mathrm{CuL}_{1} \mathrm{CuL}_{2}^{2-}$ and $\mathrm{CuLB}^{-}$is shown in Fig. 5. After taking into consideration the existence of $\mathrm{CuLB}^{-}$we obtained a better fit than the one mentioned in the Section 3.1. The

Table 2

Parameters of deconvoluted UV-vis spectra (the least square fitting parameters were $\chi^{2}=$ $2.42 \times 10^{-5}$ and $\left.\mathrm{R}^{2}=0.999994\right)$

\begin{tabular}{lll}
\hline Species & $\lambda_{\max }(\mathrm{nm})$ & $\varepsilon\left(\mathrm{M}^{-1} \mathrm{~cm}^{-1}\right)$ \\
\hline $\mathrm{CuHL}^{+}$ & 734 & 41 \\
$\mathrm{CuL}^{2-}$ & 706 & 47 \\
$\mathrm{CuL}_{2}^{2-}$ & 617 & 72 \\
$\mathrm{CuLB}^{-}$ & 643 & 48
\end{tabular}




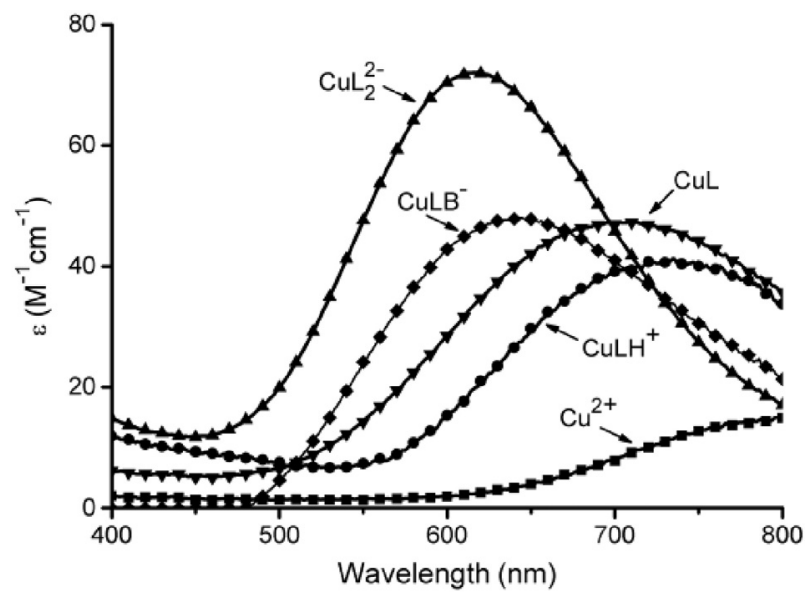

Fig. 2. The spectra of $\mathrm{Cu}(\mathrm{II})$ complexes with glutamic acid and HEPES, calculated on the basis of potentiometric data shown in Table 1, and UV-vis titration data. L denotes Glu, B denotes HEPES.

comparison of these fits is presented in Fig. S7 in the Supplementary Information file. The addition of hypothetical ternary complexes (other than $\mathrm{CuLB}^{-}$) containing $\mathrm{Cu}(\mathrm{II}), \mathrm{A} \beta_{1-16}$ and Glu did not improve the fit, because the predicted amounts of such complexes were far below the error of the estimate. This result was also consistent with UV-vis and EPR results.

\section{Discussion}

\subsection{Ternary $\mathrm{Cu}(\mathrm{II})$ complexes of $A \beta_{1-16}$}

Using potentiometry, ITC, UV-vis and EPR we obtained a comprehensive description of $\mathrm{Cu}(\mathrm{II})$ coordination equilibria in the presence of $A \beta_{1-16}$, Glu and HEPES. Contrary to our initial expectations, we proved the absence of ternary $\mathrm{Cu}(\mathrm{II})$ complexes with $A \beta_{1-16}$ and Glu. This finding has important consequences. Previously we determined the structure of a ternary complex formed by $\mathrm{Cu}(\mathrm{II})$ ion with $A \beta_{1-16}$ and 2-[(dimethylamino)methyl]-8-hydroxyquinoline [22]. In that complex the main chelating agent was the terdentate quinoline, and the

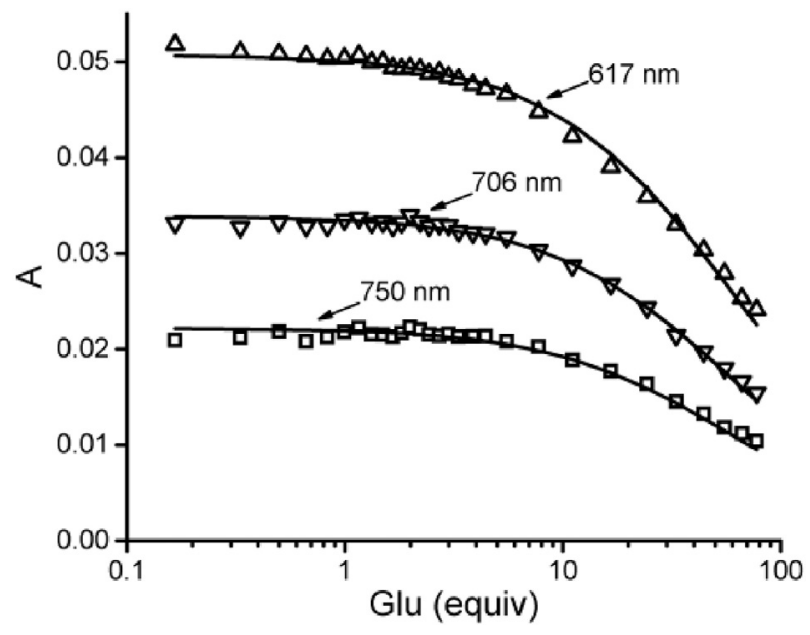

Fig. 3. Absorbance values in the $\mathrm{Cu}(\mathrm{II}) / \mathrm{A} \beta_{1-16} / \mathrm{Glu} / \mathrm{HEPES}$ system in a function of a molar ratio of Glu to $\mathrm{Cu}(\mathrm{II})$. A Glu solution $(40 \mathrm{mM})$ in $50 \mathrm{mM}$ HEPES ( $\mathrm{pH} 7.4$ ) was added to $\mathrm{Cu}(\mathrm{II}) / \mathrm{A} \beta_{1-16}$ in $50 \mathrm{mM}$ HEPES $(\mathrm{pH} 7.4)$. The best fit for the coordination model considering the presence of $\mathrm{Cu}(\mathrm{II}) / \mathrm{A} \beta_{1-16}, \mathrm{Cu}(\mathrm{II}) / \mathrm{HEPES}, \mathrm{Cu}(\mathrm{II}) / \mathrm{Glu} / \mathrm{HEPES}, \mathrm{Cu}$ (II)/Glu, and $\mathrm{Cu}(\mathrm{II}) / \mathrm{Glu}_{2}$ is represented by solid lines, at various wavelengths. The following wavelength values were selected for illustration of whole spectra fits: $617 \mathrm{~nm}$ ( $\lambda_{\max }$ for $\mathrm{CuL}_{2}$ ), $706 \mathrm{~nm}\left(\lambda_{\max }\right.$ for $\mathrm{CuL}$ ), and $750 \mathrm{~nm}$ (chosen as a wavelength at which all complex species present in the equilibrium absorb significantly).

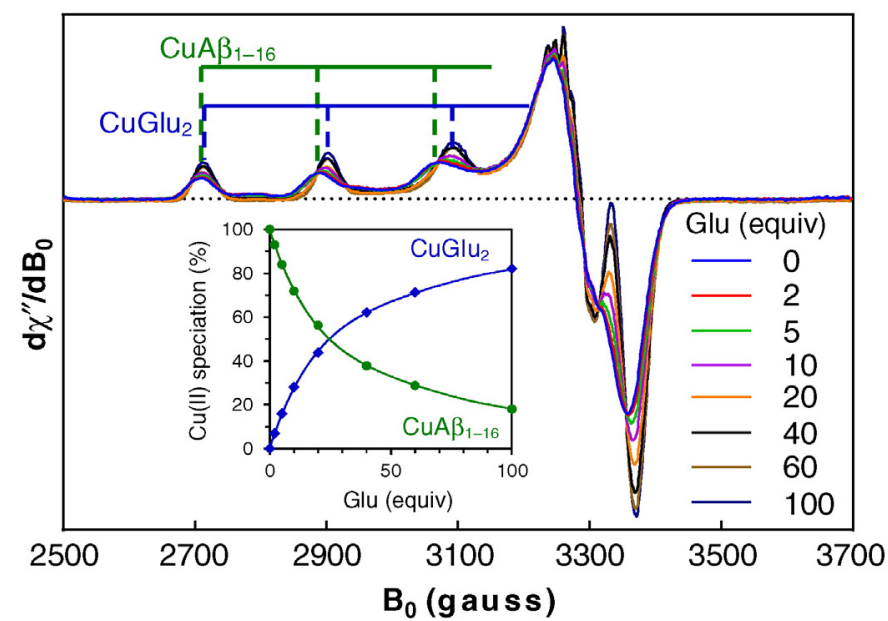

Fig. 4. X-band ( $9.45 \mathrm{GHz})$ EPR spectra ( $77 \mathrm{~K}$ ) monitoring of the titration of Glu into a solution containing $0.2 \mathrm{mM} \mathrm{Cu} / \mathrm{A} \beta_{1-16} 1: 1$ in HEPES $\mathrm{pH} 6.9$ with $10 \% \mathrm{v} / \mathrm{v}$ glycerol. Dashed vertical lines show resolved hyperfine lines corresponding to $A_{\|}\left({ }^{65} \mathrm{Cu}\right)$ for $\mathrm{CuA} \beta_{1-16}$ and $\mathrm{CuGlu}_{2}$. The speciation curves (inset) were obtained by deconvolution of the spectra (shown in Fig. S5 in the Supplementary Information file).

contribution of $A \beta_{1-16}$ to the 1st coordination sphere was via a single His residue. These two facts suggest a general rule, according to which $A \beta_{1-16}$, and more generally, $A \beta_{1-x}$ peptides, form ternary complexes preferentially by providing auxiliary His ligands to complete the coordination sphere of the $\mathrm{Cu}(\mathrm{II})$ ion pre-formed by terdentate chelating ligands. This in turn is possible when the stability constant of the binary complex with the terdentate ligand is higher than that of the $\mathrm{CuA} \beta_{1-\mathrm{x}}$ complex. Glutamic acid, and generally amino acids except perhaps His, do not meet this criterion. Incidentally, this finding provides an additional argument for the validity of the method of determination of binding constants of $\mathrm{Cu}$ (II) complexes with $\mathrm{A} \beta$ peptides based on Gly as competitive ligand [5].

\subsection{Re-evaluated stability constants for the $\mathrm{Cu}(\mathrm{II}) / \mathrm{Glu}$ system and $\mathrm{Cu}(\mathrm{II})$ binding in the synaptic cleft}

The full characterization of the $\mathrm{Cu}(\mathrm{II}) / \mathrm{A} \beta_{1-16} / \mathrm{Glu}$ system in terms of stability constants empowered us to investigate the potential impact of the neurotransmitter (Glu) on the likelihood of formation of $\mathrm{Cu}$ (II) complexes of $A \beta_{1-x}$ peptides in the synaptic cleft, the most probable localization of neurotoxic reactivity of these $A \beta_{1-x}$ peptides [1]. We calculated the distribution of $\mathrm{Cu}(\mathrm{II})$ ions between $A \beta_{1-16}$ and Glu for several concentrations of reagents possibly relevant for the conditions in the synaptic cleft (Fig. 6). Glu is a neurotransmitter, with peak concentrations higher than $1 \mathrm{mM}$ shortly after its release from the presynaptic neuron, but falling to low micromolar values prior to the next burst [23]. To simplify these model calculations, we fixed Glu concentration at $2 \mathrm{mM}$, to represent this burst. We set $\mathrm{Cu}$ (II) and $\mathrm{A} \beta$ to be equimolar and varied their concentrations between $1 \mu \mathrm{M}$ and $300 \mu \mathrm{M}$. The lower limit corresponds to just a few atoms/molecules in the synaptic cleft, the upper one is similar to the highest $\mathrm{Cu}(\mathrm{II})$ concentration observed during neurotransmission [31,32], and the average concentration of $\mathrm{Cu}(\mathrm{II})$ in the synaptic cleft, derived from measurements done in synaptosomes, of $14 \mu \mathrm{M}$, is within this range [33]. Interestingly, our calculations show that Glu could significantly reduce the amount of $\mathrm{A} \beta$ bound $\mathrm{Cu}(\mathrm{II})$ ions, especially at a low abundance of $\mathrm{CuA} \beta$. Therefore, Glu and similar small molecules could have an additional function in clearing $\mathrm{Cu}$ (II) ions from the synaptic cleft, and thus preventing the formation of deleterious $C u A \beta_{1-x}$ complexes. Notably, under the conditions of our calculations the abundance of $\mathrm{Glu}$ bound $\mathrm{Cu}$ (II) ions never exceeded $1 \%$ of the total neurotransmitter, and thus this hypothetical interaction would not likely interfere with neurotransmission. 

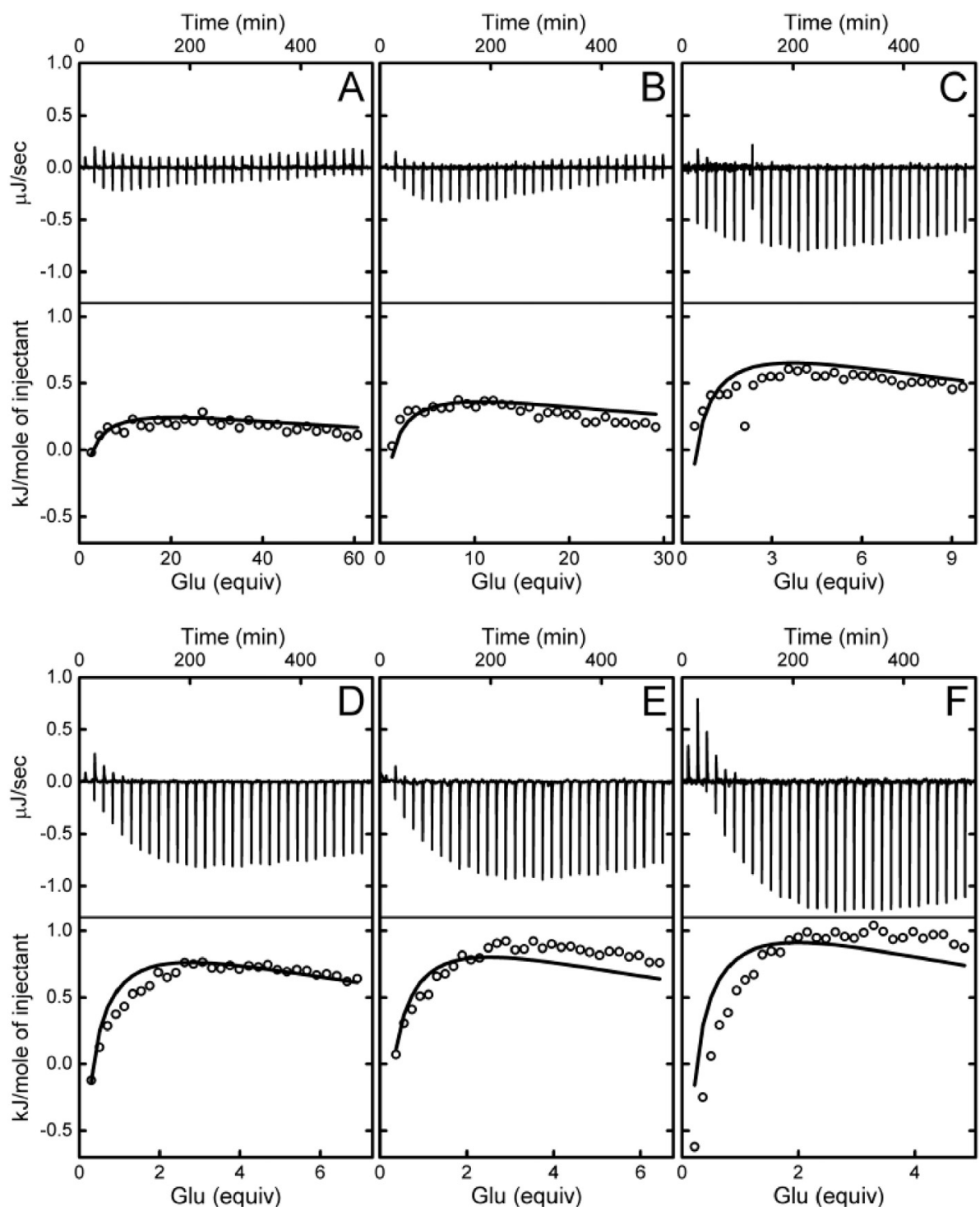

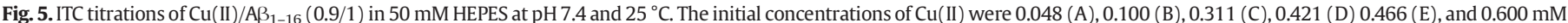

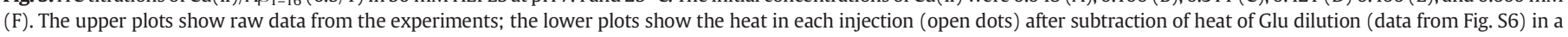

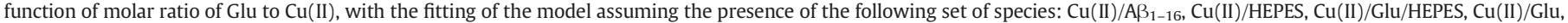
and $\mathrm{Cu}(\mathrm{II}) / \mathrm{Glu}_{2}$. Values of $\log \beta$ were derived from ref. [5] for $\mathrm{Cu}(\mathrm{II}) / \mathrm{A} \beta_{1-16}$, ref. [28] for $\mathrm{Cu}(\mathrm{II}) / \mathrm{HEPES}$, and from potentiometric experiments (this paper) for all other complexes.

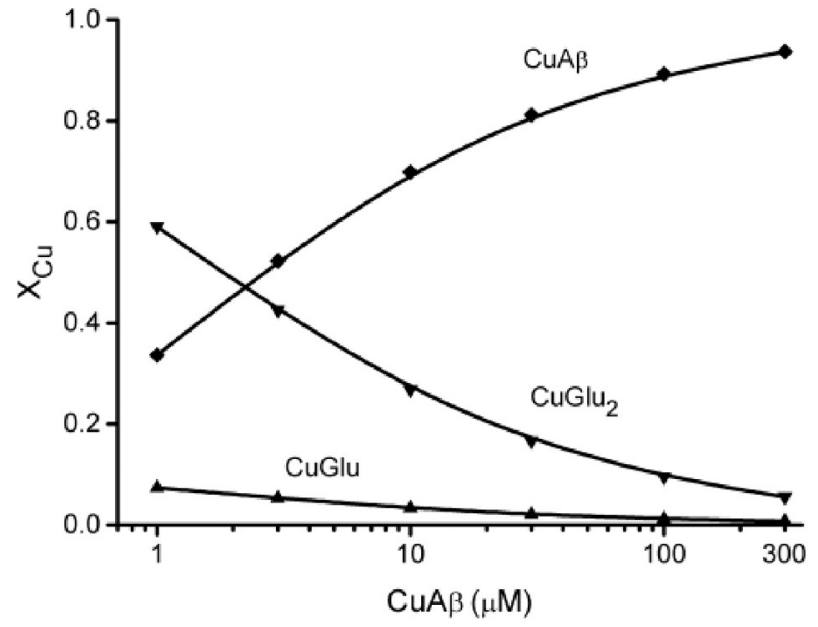

Fig. 6. $\mathrm{Cu}(\mathrm{II})$ species distribution simulated for a range of equimolar concentrations of $\mathrm{Cu}(\mathrm{II})$ and $\mathrm{A} \beta$ (from 1 to $300 \mu \mathrm{M}$ ) and $2 \mathrm{mM}$ Glu at $\mathrm{pH}$ 7.4.

\section{Conclusions}

Our study provided three significant results. The nonexistence of ternary complexes with Glu (and, more broadly, with amino acids) in a system containing equimolar $\mathrm{Cu}(\mathrm{II})$ and $\mathrm{A} \beta$ provides a significant benchmark for studies of chemistry of these complexes. A tentative rule on formation of such ternary complexes will assist studies on $\mathrm{Cu}$ (II) chelating agents as potential AD drugs. Finally, our quantitative results indicate that Glu released in the process of neurotransmission may be part of the synaptic clearance system for $\mathrm{Cu}(\mathrm{II})$ ions preventing the formation of neurotoxic complexes of $A \beta$ peptides.

\section{Acknowledgments}

This work was supported by the Foundation for Polish Science TEAM Program, co-financed from European Regional Development Fund resources within the framework of Operational Program Innovative Economy under the project "Metal-Dependent Peptide Hydrolysis Tools and Mechanisms for Biotechnology, Toxicology and Supramolecular Chemistry" (TEAM 2009-4/1) to W.B. The equipment used was 
sponsored in part by the Centre for Preclinical Research and Technology (CePT), a project cosponsored by the European Regional Development Fund and Innovative Economy, The National Cohesion Strategy of Poland. S.C.D was supported by a Future Fellowship (FT110100199) administered by the Australian Research Council.

\section{Appendix A. Supplementary data}

Supplementary data to this article can be found online at http://dx. doi.org/10.1016/j.jinorgbio.2016.02.035.

\section{References}

[1] K.J. Barnham, A.I. Bush, Metals in Alzheimer's and Parkinson's diseases, Curr. Opin. Chem. Biol. 12 (2008) 222-228.

[2] C. Hureau, Coordination of redox active metal ions to the amyloid precursor protein and to amyloid- $\beta$ peptides involved in Alzheimer disease. Part 1: An overview, Coord. Chem. Rev. 256 (2012) 2164-2174.

[3] E. Gaggelli, H. Kozlowski, D. Valensin, G. Valensin, Copper homeostasis and neurodegenerative disorders (Alzheimer's, prion, and Parkinson's diseases and amyotrophic lateral sclerosis), Chem. Rev. 106 (2006) 1995-2044.

[4] S. Chassaing, F. Collin, P. Dorlet, J. Gout, C. Hureau, P. Faller, Copper and hememediated abeta toxicity: redox chemistry, abeta oxidations and anti-ROS compounds, Curr. Top. Med. Chem. 12 (2012) 2573-2595.

[5] B. Alies, E. Renaglia, M. Rózga, W. Bal, P. Faller, C. Hureau, Cu(II) affinity for the Alzheimer's peptide: tyrosine fluorescence studies revisited, Anal. Chem. 85 (2013) 1501-1508

[6] T.R. Young, A. Kirchner, A.G. Wedd, Z. Xiao, An integrated study of the affinities of the $\mathrm{AB} 16$ peptide for $\mathrm{Cu}(\mathrm{I})$ and $\mathrm{Cu}(\mathrm{II})$ : implications for the catalytic production of reactive oxygen species, Metallomics 6 (2014) 505-517.

[7] M. Rózga, M. Sokołowska, A.M. Protas, W. Bal, Human serum albumin coordinates $\mathrm{Cu}(\mathrm{II})$ at its $\mathrm{N}$-terminal binding site with $1 \mathrm{pM}$ affinity, J. Biol. Inorg. Chem. 12 (2007) 913-918.

[8] F. Licastro, M.C. Morini, L.J. Davis, R. Biagi, L. Prete, G. Savorani, Studies of blood brain barrier permeability and of intrathecal IgG synthesis in patients with Alzheimer's disease and multi-infarct dementia, Adv. Biosci. 87 (1993) 283-284 (Oxford).

[9] L. Perrone, E. Mothes, M. Vignes, A. Mockel, C. Figueroa, M.-C. Miquel, M.-L Maddelein, P. Faller, Copper transfer from Cu-Abeta to human serum albumin inhibits aggregation, radical production and reduces Abeta toxicity, ChemBioChem. 11 (2010) 110-118.

[10] M. Rózga, W. Bal, The $\mathrm{Cu}(\mathrm{II}) / \mathrm{A} / \mathrm{HSA}$ model of control mechanism for copperrelated amyloid neurotoxicity, Chem. Res. Toxicol. 23 (2010) 298-308.

[11] V. Tõugu, A. Tiiman, P. Palumaa, Interactions of $\mathrm{Zn}(\mathrm{II})$ and $\mathrm{Cu}(\mathrm{II})$ ions with Alzheimer's amyloid-beta peptide. metal ion binding, contribution to fibrillization and toxicity, Metallomics 3 (2011) 250-261.

[12] N. Lu, Q. Yang, J. Li, R. Tian, Y. Peng, Inhibitory effect of human serum albumin on Cuinduced AB40 aggregation and toxicity, Eur. J. Pharmacol. 767 (2015) 160-164.

[13] M. Mital, N.E. Wezynfeld, T. Frączyk, M.Z. Wiloch, U.E. Wawrzyniak, A. Bonna, C. Tumpach, K.J. Barnham, C.L. Haigh, W. Bal, S.C. Drew, A functional role for A $\beta$ in metal homeostasis? N-truncation and high-affinity copper binding, Angew. Chem. Int. Ed. Engl. 54 (2015) 10460-10464.

[14] C.L. Masters, G. Simms, N.A. Weinman, G. Multhaup, B.L. McDonald, K. Beyreuther, Amyloid plaque core protein in Alzheimer disease and Down syndrome, Proc. Natl. Acad. Sci. U. S. A. 82 (1985) 4245-4249.

[15] C.L. Masters, G. Multhaup, G. Simms, J. Pottgiesser, R.N. Martins, K. Beyreuther, Neuronal origin of a cerebral amyloid: neurofibrillary tangles of Alzheimer's disease contain the same protein as the amyloid of plaque cores and blood vessels, EMBO J. 4 (1985) 2757-2763.

[16] H. Lewis, D. Beher, N. Cookson, A. Oakley, M. Piggott, C.M. Morris, E. Jaros, R. Perry, P. Ince, R.A. Kenny, C.G. Ballard, M.S. Shearman, R.N. Kalaria, Quantification of Alzheimer pathology in ageing and dementia: age-related accumulation of amyloid-beta(42) peptide in vascular dementia, Neuropathol. Appl. Neurobiol. 32 (2006) 103-118.

17] E. Portelius, N. Bogdanovic, M.K. Gustavsson, I. Volkmann, G. Brinkmalm, H. Zetterberg, B. Winblad, K. Blennow, Mass spectrometric characterization of brain amyloid beta isoform signatures in familial and sporadic Alzheimer's disease, Acta Neuropathol. 120 (2010) 185-193.

[18] C.J. Sarell, C.D. Syme, S.E. Rigby, J.H. Viles, Copper(II) binding to amyloid-beta fibrils of Alzheimer's disease reveals a picomolar affinity: stoichiometry and coordination geometry are independent of abeta oligomeric form, Biochemistry 48 (2009) 4388-4402.

[19] D. Jiang, L. Zhang, G.P. Grant, C.G. Dudzik, S. Chen, S. Patel, Y. Hao, G.L. Millhauser, F. Zhou, The elevated copper binding strength of amyloid- $\beta$ aggregates allows the sequestration of copper from albumin: a pathway to accumulation of copper in senile plaques, Biochemistry 52 (2013) 547-556.

[20] M. Rózga, A.M. Protas, A. Jabłonowska, M. Dadlez, W. Bal, The Cu(II) complex of A 340 peptide in ammonium acetate solutions. Evidence for ternary species formation, Chem. Commun. (2009) 1374-1376.

[21] Y. Bin, Z. Jiang, J. Xiang, Side effect of Tris on the interaction of amyloid $\beta$-peptide with $\mathrm{Cu}^{2+}$ : evidence for Tris-A $\beta-\mathrm{Cu}^{2+}$ ternary complex formation, Appl. Biochem. Biotechnol. 176 (2015) 56-65.

[22] V.B. Kenche, I. Zawisza, C.L. Masters, W. Bal, K.J. Barnham, S.C. Drew, Mixed ligand $\mathrm{Cu}^{2+}$ complexes of a model therapeutic with Alzheimer's amyloid- $\beta$ peptide and monoamine neurotransmitters, Inorg. Chem. 52 (2013) 4303-4318.

[23] N.C. Danbolt, Glutamate uptake, Prog. Neurobiol. 65 (2001) 1-105.

[24] H. Irving, M.G. Miles, L.D. Pettit, A study of some problems in determining the stoicheiometric proton dissociation constants of complexes by potentiometric titrations using glass electrode, Anal. Chim. Acta 38 (1967) 475-488.

[25] P. Gans, A. Sabatini, A. Vacca, SUPERQUAD: an improved general program for computation of formation constants from potentiometric data, J. Chem. Soc. Dalton Trans. (1985) 1195-1200.

26] P. Gans, A. Sabatini, A. Vacca, Investigation of equilibria in solution determination of equilibrium constants with the HYPERQUAD suite of programs, Talanta 43 (1996) $1739-1753$.

27] S.C. Drew, C.J. Noble, C.L. Masters, G.R. Hanson, K.J. Barnham, Pleomorphic coppe coordination by Alzheimer's disease amyloid-beta peptide, J. Am. Chem. Soc. 131 (2009) 1195-1207.

[28] M. Sokołowska, W. Bal, Cu(II) complexation by "non-coordinating" N-2 hydroxyethylpiperazine-N'-2-ethanesulfonic acid (HEPES buffer), J. Inorg. Biochem. 99 (2005) 1653-1660.

[29] M. Rózga, M. Kłoniecki, M. Dadlez, W. Bal, A direct determination of the dissociation constant for the $\mathrm{Cu}(\mathrm{II})$ complex of amyloid beta 1-40 peptide, Chem. Res. Toxicol. 23 (2010) 336-340.

[30] G. Brookes, L.D. Pettit, Complex formation and stereoselectivity in the ternary systems copper(II)-D/L-histidine-L-amino-acids, J. Chem. Soc. Dalton Trans. (1977) 1918-1924

[31] D.E. Hartter, A. Barnea, Evidence for release of copper in the brain: depolarizationinduced release of newly taken-up 67copper, Synapse 2 (1988) 412-415.

[32] J. Kardos, I. Kovács, F. Hajós, M. Kálmán, M. Simonyi, Nerve endings from rat brain tissue release copper upon depolarization. A possible role in regulating neuronal excitability, Neurosci. Lett. 103 (1989) 139-144

[33] A. Hopt, S. Korte, H. Fink, U. Panne, R. Niessner, R. Jahn, H. Kretzschmar, J. Herms, Methods for studying synaptosomal copper release, J. Neurosci. Methods 128 (2003) 159-172. 